Received $\quad 04.06 .2017$

Reviewed 03.07.2017

Accepted 07.07.2017

A - study design

B - data collection

C - statistical analysis

D - data interpretation

$\mathbf{E}$ - manuscript preparation

F - literature search

\title{
Increase in the number of submitted maps for design purposes as a determinant of proper spatial planning policy
}

\author{
Agnieszka BIEDA ${ }^{\text {ABCDEF } 凶}$
}

AGH University of Science and Technology, al. A. Mickiewicza 30, 30-059 Kraków, Poland; e-mail: bieda@agh.edu.pl

For citation: Bieda A. 2017. Increase in the number of submitted maps for design purposes as a determinant of proper spatial planning policy. Journal of Water and Land Development. No. 34 p. 65-75. DOI: 10.1515/jwld-20170039.

\begin{abstract}
Spatial planning policy is to set objectives and means through which public administrative authorities intend to shape the development of a specific area. This policy is to lead to the most rational use of the human environment. It is supported by spatial planning which, using local land use plans, helps clarify the concept of spatial planning policy, and it is also actively involved in its implementation. Spatial planning may not, however, exist independently. It is clearly related to other areas, without which the implementation of the spatial planning policy would be impossible. Surveying and construction are those sectors which are undoubtedly related to spatial planning. Surveying studies determine the location of future objects defined in the planning processes, whereas these structures are implemented in investment processes. The above correlation suggests a conclusion regarding the possibility to use building processes, as well as the preceding surveying work, as the indicator of the correct implementation of the spatial planing policy. In order to verify whether the number and location of investments may be in fact associated with the general concept contained in the spatial planning policy, the analysis of the spatio-temporal distribution of surveying works initiating the construction processes was performed, i.e. maps for design purposes for the town of Niepołomice. The resulting cartographic studies were compared with graphic enclosures to the planning documents prepared for the area within the administrative boundaries of the town. The studies were performed for the years 2003-2015.
\end{abstract}

Key words: construction process, density map, local land use plan, map for design purposes, spatial planning policy

\section{INTRODUCTION}

Space development is systematically regulated through spatial planning policy, spatial decision making mechanisms, and spatial planning [BORSA 2004]. These activities are closely related. However, spatial policy is the overriding concept. It deals with the objectives and means of practical implementation of procedures related to shaping, using and transforming the human environment in the most rational way. It is implemented in specific, time-variable external (social, economic, technical, political) conditions. Proper spatial planning policy leads to spatial order and sustainable development [Ustawa... 2003]. Its results in the shaping of desirable space to be maintained over the years [MACLAREN 1996]. Spatial planning policy creates specific ideas, directions, laws and principles [KORELESKI 2009]. Spatial decisions and spatial planning are only supporting elements, which help to make it more specific and then to implement it.

However, the implementation of spatial planning policy would be impossible without involvement of other domains which allow to actually make records of planning documents. The fields that render the implementation of spatial policy possible include: real estate management, construction and surveying, which is associated with them [BIEDA et al. 2012]. Figure 1 demonstrates the dependence between them. 


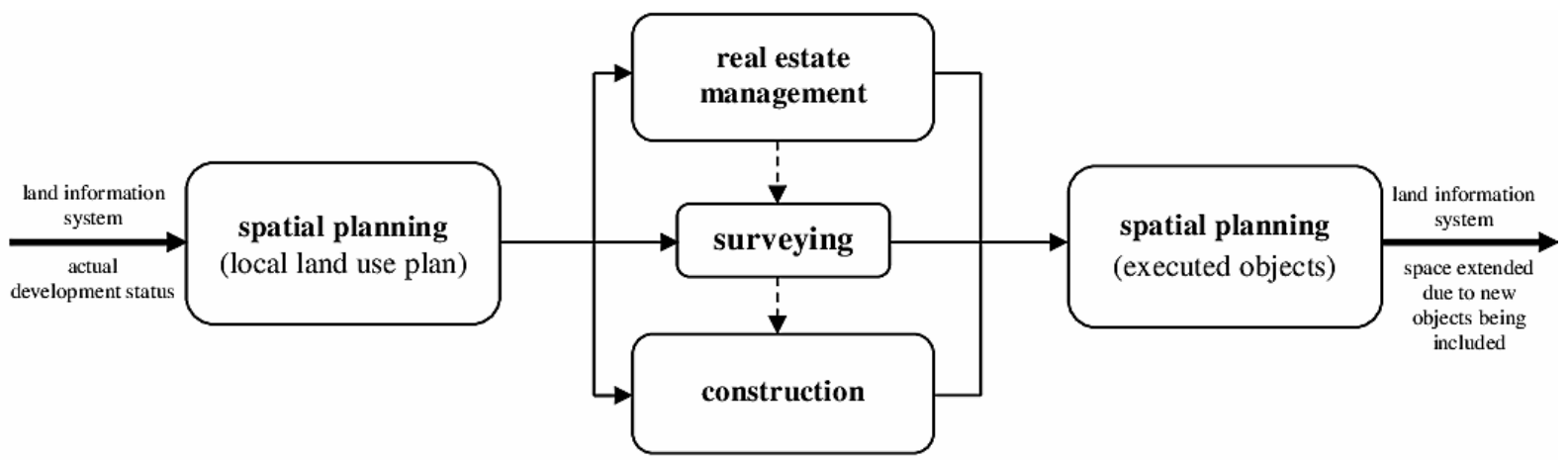

Fig. 1. Diagram of dependencies between spatial planning, real estate management, surveying and construction; source: own elaboration based on BIEDA et al. [2012]

Describing the diagram of dependencies, it should be mentioned that:

- spatial planning answers the question of where building structures that will change space in the future are being planned;

- real estate management answers the question of what the scope and basis of space changes regarding structures presented in the planning process are;

- surveying answers the question of how to determine the location of structures determined in the planning process and which change space;

- construction answers the question of how to implement physically planned objects whose location has been determined in space by surveying methods.

Space changes are based mainly on the principle of the so-called good neighborhood, i.e. by maintaining the existing spatial development. This means that spatial policy can be conducted by duplicating specific objects such as buildings and road or technical infrastructure networks [ŚLESZYŃSKI 2013]. Therefore, the right spatial policy is the one that brings about intensification of new developments in the areas intended for this specific purpose. The case studies presented KOPACZ and TWARDY [2013], PIASECKI and JURASZ [2015], BALAWEJDER and NOGA [2016], GRZYWNA and SENDER [2017] demonstrate that human environment is constantly changing as a result of both natural and anthropogenic factors. Therefore, each planning document must take into account land management, which already exists and is continuously modified [ADAMCZYK et al. 2014].

\section{OBJECTIVE AND SCOPE OF THE STUDY}

Analyses carried out for Krakow demonstrated that it was possible to determine potential changes in the number of surveying works performed (real estate subdivisions, maps for design purposes and as-built surveys) based on existing planning documents [BACIOR et al. 2015]. This is because the objective of local land use plans is to activate investment processes [BIEDA, PARZYCH 2013].

In this paper, a reverse thesis was formulated. The objective is to verify whether the information on the change of development status illustrated in the docu- mentation accepted into the National Geodetic and Cartographic Documentation Center (Pol. Państwowy Zasób Geodezyjny i Kartograficzny) database can be used as an indicator of spatial policy correctness. This indicator has not been discussed yet in the available Polish studies dealing with the issue of the assessment of spatial order, that is, in papers by CYMERMAN and PODCIBORSKI [2004] and ŚLESZYŃSKI [2013]. The world literature is also based mainly on the changes that had already taken place in spatial planning, identifying changes in density of erected residential buildings, as in papers by GENNAIO et al. [2009] and SALVATI et al. [2012] or density of road networks [ZHANG et al. 2002].

According to the author, intensity of surveying works performed during the investment process may define the change in the development status. These can include: preparation of maps for design purposes, setting-out procedures and as-built surveying. In order to determine whether they are actually associated with the general concept contained in the spatial policy of the analyzed area, it is suggested to compare their spatiotemporal distribution with the basic instrument of spatial policy which is a local land use plan.

Submission of a survey on preparation of a map for design purposes expresses an intention to commence an investment process. Without this study, it is not possible to create documentation to be granted a construction permit or to submit a notification of construction [Ustawa... 1994]. Setting-out procedures initiate the actual construction, while as-built surveys mean its completion. Nevertheless, there is no certainty as to how long the design work and the construction process lasted. Hence, setting-out procedures and as-built surveys are difficult to relate in time to specific spatial planning processes and, as a consequence, to be considered a reliable indicator of change in development status.

\section{DATA AND RESEARCH METHODOLOGY}

The formulated hypothesis was verified by examining the described relationships for the town of Niepołomice. The analyses presented in this article were performed based on the data provided by the District 
Geodetic and Cartographic Documentation Center in Wieliczka, contained on the website of the Town and Commune Office of Niepołomice and from the Central Geodetic and Cartographic Documentation Database (Pol. Centralny Zasób Geodezyjny i Kartograficzny). The data which were used to determine the dependencies between spatial planning and investment processes are as follows:

- register of surveying works carried out within administrative boundaries of Niepołomice;

- spatial data on record parcels within administrative boundaries of Niepołomice;

- data on population density in Niepołomice;

- data on boundaries of local land use plans in Niepołomice;

- content of the resolutions of the Town Council in Niepołomice on the local land use plans in force for Niepołomice;

- data from the National Register of Boundaries and areas of territorial division units of the country;

- digital orthophotomap of 2015 with a pixel size of $0.25 \mathrm{~m}$.

During the analyzed period (1.01.200331.12.2015), 2443 maps for design purposes were submitted in Niepołomice. A diagram in Figure 2 illustrates their number in individual years, and spatial distribution of centroids of record parcels covered by submitted maps for design purposes is demonstrated in Figure 3.

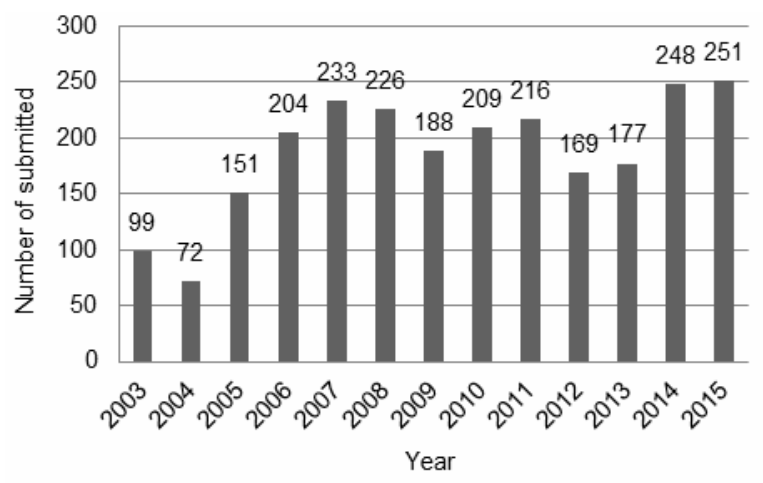

Fig. 2. Annual number of submitted maps for design purposes within the administrative boundaries

of Niepołomice; source: own study based on the data from the District Geodetic and Cartographic

Documentation Center in Wieliczka

Annual number of surveys submitted with reference to the preparation of a map for design purposes ranges from 72 to 251 . In the years 2003-2015, this number can be described as growing. It is presumably a result of increased interest of potential investors to commence the construction process.

On the other hand, spatial distribution of the centroids of record parcels covered by the submitted maps for design purposes demonstrates that investors potentially interested in starting an investment are active in the areas with some development already. This is not surprising - it is probably associated with a possibility to build according to the existing planning documents and with availability of infrastructure.

The main spatial feature of Niepołomice is clear separation of three functional zones [Uchwała $\mathrm{nr}$ LXIII/629/10]:

1) town center with historic foundations of the castle and the church as well as developed services;

2) housing-agricultural-recreational areas covering the eastern part of the town;

3) industrial zone - developed in the western part of the town.

This division is clearly visible on the orthophotomap of Niepołomice in Figure 4.

The main objective of the town's spatial policy is to maintain this division. Therefore, local land use plans are created to prevent improper development, or development in general, in the areas with specific functionality.

The first local land use plan for Niepołomice was established in 2005. It covered almost the whole town (without a fragment of the Niepołomice Primeval Forest in the south and a special economic zone in the west). In the following years, new planning documents were prepared. Figure 5 illustrates their current range, and their description is contained in Table 1.

Local land use plans, which covered the largest areas were prepared in 2007 and 2014 (approximately $1 / 3$ of the total area of the town). In 2007, a document for the Niepołomice Industrial Zone was finally adopted. It specified main areas for production, technical, and service purposes. In 2014, updates were made regarding parts of the districts of Jazy, Podgrabie and Zagrody (northern part of the town), extending the area intended for single family housing.

It was decided that density of spatial distribution of record parcels covered by the submitted maps for design purposes, determined before and after the entry into force of subsequent resolutions on local land use plans, could be used as an indicator of change in development status. Since the preparation of a local land use plan is a long-term procedure, and its launch can affect the decisions of potential investors, the analyses were carried out mainly in annual and long-term periods. They were conducted in several stages:

1) density of spatial distribution of record parcels covered by submitted maps for design purposes in the years 2003-2015 was compared with the population density of the town;

2) density maps of spatial distribution of record parcels covered by submitted maps for design purposes were created, in points in time which were important for the spatial development of Niepołomice;

3) annual density of spatial distribution of record parcels covered by submitted maps for design purposes within the boundaries of individual local land use plans was determined.

All density maps were prepared using the quantitative field-mapping method [CICHOCIŃSKI 2007] Squares of 4 hectares were used as a reference field. 


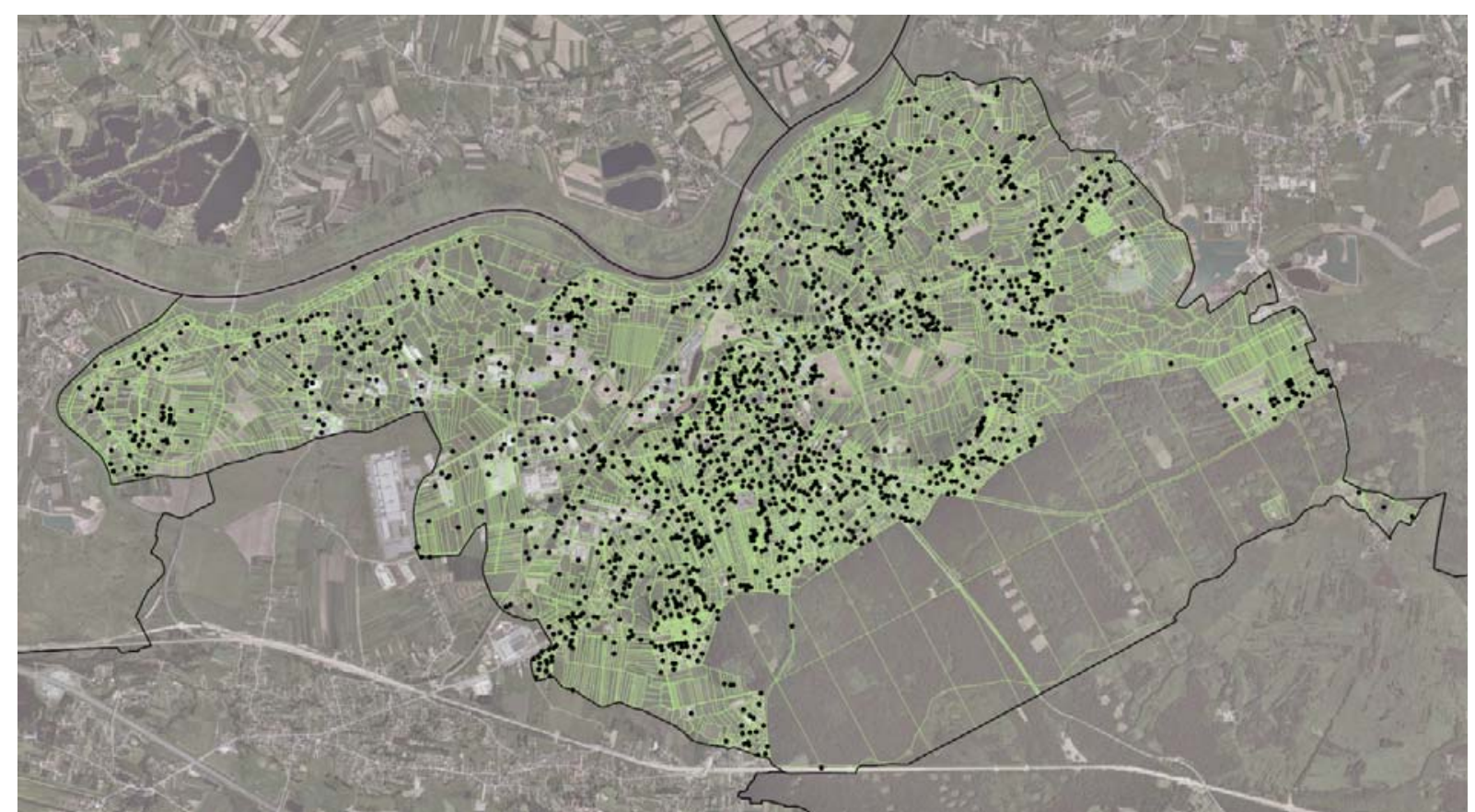

Fig. 3. Spatial distribution of centroids of record parcels covered by submitted maps for design purposes within administrative boundaries of the town of Niepołomice; source: own study based on the data from the District Geodetic and Cartographic Documentation Center in Wieliczka

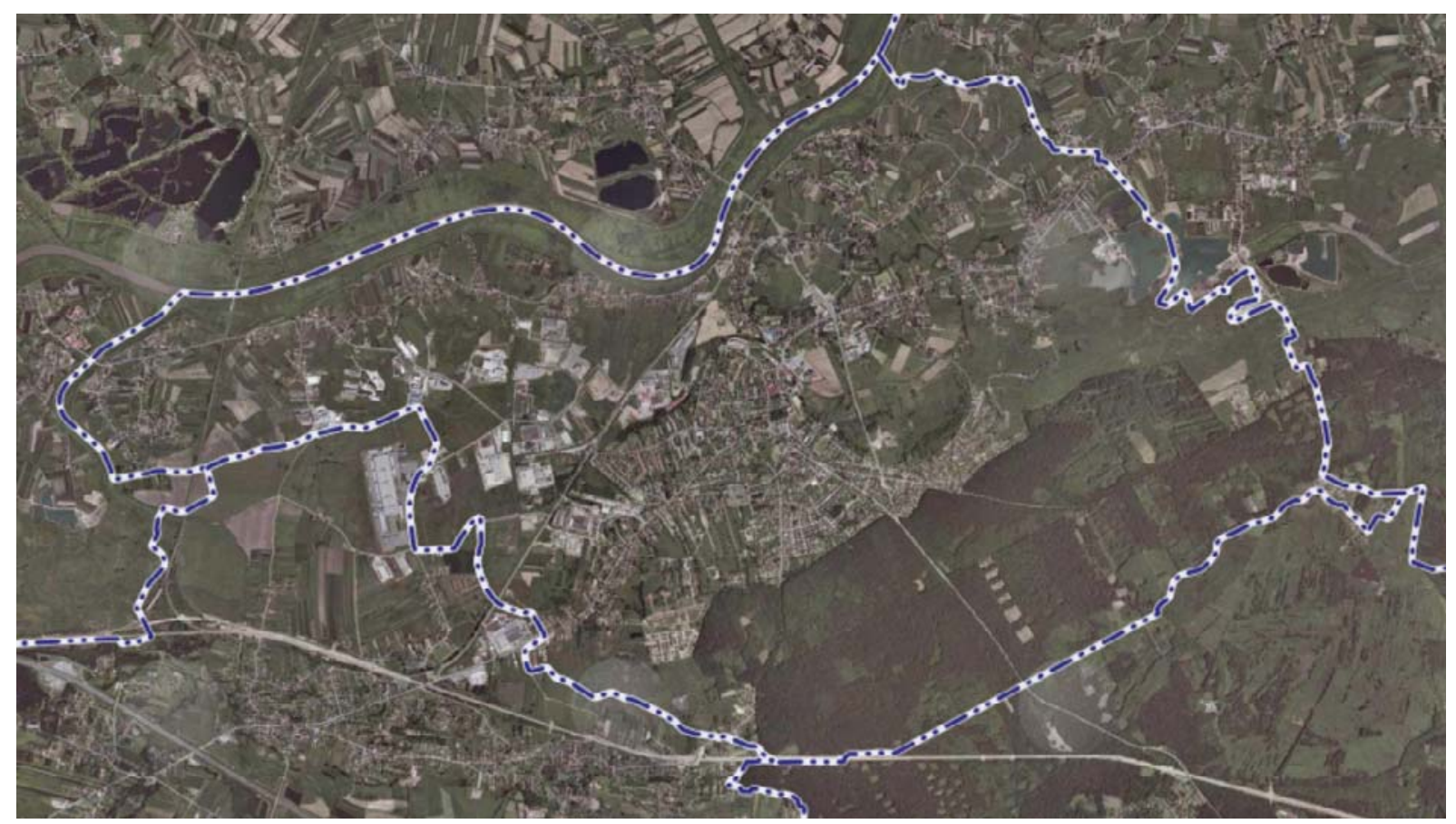

Fig. 4. Functional zones in Niepołomice; source: Miasto i Gmina... [undated]

\section{DISCUSSION}

\section{AND ANALYSIS OF THE RESULTS}

In order to compare density of spatial distribution of record parcels covered by submitted maps for design purposes with the town population density in the years 2003-2015 (Fig. 6), a map presented in Figure 7 was prepared.

In the analyzed period, the intention to start an investment process (over 20 submissions) could be most frequently noted in the strict town center of Niepołomice and in Jazy district.

By comparing the density map with the population density, it is clear that there is no information on any resident registered in the area of the Niepołomice Industrial Zone; there are investments only.

The remaining areas, however, demonstrate a relationship between the number of registered residents and the number of maps for design purposes submitted there. 


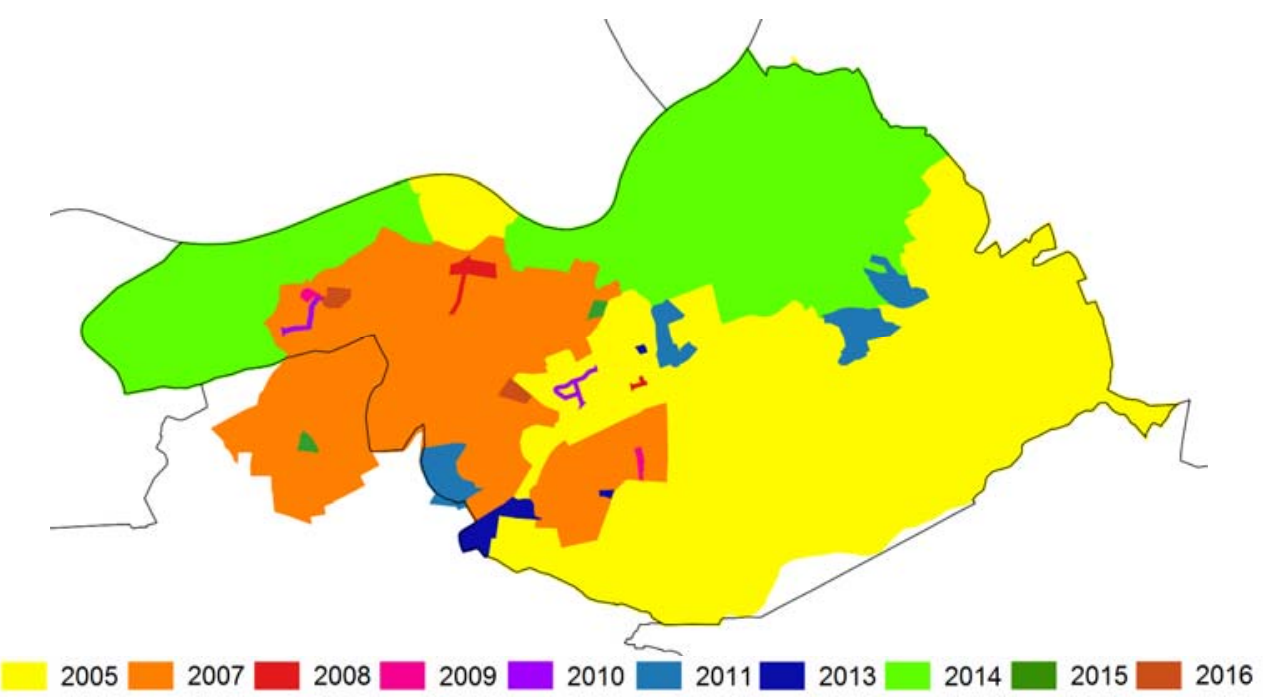

Fig. 5. Local land use plans adopted for the town of Niepołomice in 2005-2016; source: own study

Table 1. Local land use plans adopted for the town of Niepołomice in 2005-2016

\begin{tabular}{|c|c|c|r|c|}
\hline $\begin{array}{c}\text { Date of } \\
\text { resolution }\end{array}$ & $\begin{array}{c}\text { Date of } \\
\text { publication }\end{array}$ & $\begin{array}{c}\text { In force } \\
\text { since }\end{array}$ & $\begin{array}{c}\text { Area } \\
\text { ha }\end{array}$ & $\begin{array}{c}\text { Percentage } \\
\text { of change }\end{array}$ \\
\hline 12.04 .2005 & 09.06 .2005 & 25.06 .2005 & 2520.00 & - \\
\hline 16.01 .2007 & 21.03 .2007 & 21.04 .2007 & 651.84 & 25.87 \\
\hline 16.01 .2007 & 21.03 .2007 & 21.04 .2007 & 86.72 & 3.44 \\
\hline 21.02 .2008 & 25.03 .2008 & 25.04 .2008 & 0.14 & 0.01 \\
\hline 02.09 .2008 & 29.09 .2008 & 29.09 .2008 & 4.50 & 0.18 \\
\hline 31.08 .2009 & 28.09 .2009 & 28.10 .2009 & 0.63 & 0.03 \\
\hline 29.12 .2009 & 31.12 .2009 & 30.01 .2010 & 0.73 & 0.03 \\
\hline 25.05 .2010 & 10.06 .2010 & 10.07 .2010 & 0.74 & 0.03 \\
\hline 25.05 .2010 & 11.08 .2010 & 11.09 .2010 & 0.56 & 0.02 \\
\hline 29.03 .2011 & 13.04 .2011 & 13.05 .2011 & 10.90 & 0.43 \\
\hline 04.05 .2011 & 26.05 .2011 & 26.06 .2011 & 10.17 & 0.40 \\
\hline 31.08 .2011 & 20.09 .2011 & 20.10 .2011 & 19.00 & 0.75 \\
\hline 31.08 .2011 & 20.09 .2011 & 20.10 .2011 & 16.50 & 0.65 \\
\hline 03.09 .2013 & 16.09 .2013 & 01.10 .2013 & 0.30 & 0.01 \\
\hline 03.09 .2013 & 16.09 .2013 & 01.10 .2013 & 12.00 & 0.48 \\
\hline 03.09 .2013 & 16.09 .2013 & 01.10 .2013 & 0.23 & 0.01 \\
\hline 27.06 .2014 & 07.08 .2014 & 22.08 .2014 & 256.00 & 10.16 \\
\hline 27.06 .2014 & 08.08 .2014 & 23.08 .2014 & 446.00 & 17.70 \\
\hline 27.06 .2014 & 07.08 .2014 & 22.08 .2014 & 116.00 & 4.60 \\
\hline 28.05 .2015 & 16.06 .2015 & 01.07 .2015 & 1.47 & 0.06 \\
\hline 28.05 .2015 & 16.06 .2015 & 01.07 .2015 & 1.33 & 0.05 \\
\hline 05.05 .2016 & 08.06 .2016$. & 23.05 .2016 & 2.90 & 0.12 \\
\hline 05.05 .2016 & 31.05 .2016 & 15.06 .2016 & 2.72 & 0.11 \\
\hline
\end{tabular}

Source: own study.

The years which were considered important for spatial development of Niepołomice were as follows: 2005 (entry into force of the first land use plan), 2007 (entry into force of the plan for the Niepołomice Industrial Zone) and 2014 (increase in residential development in the districts of Jazy, Podgrabie and Zagrody). This formed the basis for the preparation of density maps in 4 time intervals:

1) years 2003-2004 (Fig. 8), which preceded the entry into force of the local land use plan for the town of Niepołomice;

2) years 2004-2006 (Fig. 9), when a procedure for the preparation of the local land use plan for the town of Niepołomice took place (2004-2005) and when this plan just came into force (2005-2006);

3) years 2006-2008 (Fig. 10), when the local land use plan for the Niepołomice Industrial Zone was in progress (2006) and when this plan just came into force (2007-2008);

4) years 2013-2015 (Fig. 11), when a procedure for the preparation of the local land use plan for Jazy, Podgrabie and Zagrody took place (2013-2014) and when this plan just came into force (20142015).

In Figures $8-11$, it is clearly noticeable that there is a dependence between the preparation of local land use plans and the intensity of investment processes. Density of spatial distribution of record parcels that were covered by the submitted maps for design purposes in the years prior to the adoption of the local land use plan for the town is much lower than in other cases. In total, 172 maps for design purposes were submitted during these two years. In subsequent years, the same number of submissions were made for one year (cf. the diagram in Fig. 3).

At the time when the local land use plan for Niepołomice was being prepared and immediately after its adoption, the number of submitted maps for design purposes increased significantly. In 2005 they doubled, and in 2006 there were already three times more than in the year preceding the adoption of the plan. Their spatial distribution coincided with the already inhabited areas. The exception is the area of the Niepołomice Industrial Zone where, despite the lack of a plan, individual works started in 2005 and predicted future investments. However, density of record parcels covered by maps for design purposes increased considerably only just in the years 2006-2008 (Fig. $10)$, i.e. after the adoption of the plan.

An increased interest in potential investments is also demonstrated in Figure 11. The plan for Jazy district was updated and, as a result, the number of maps for design purposes reached 10 for one of the squares in 2013-2015. 


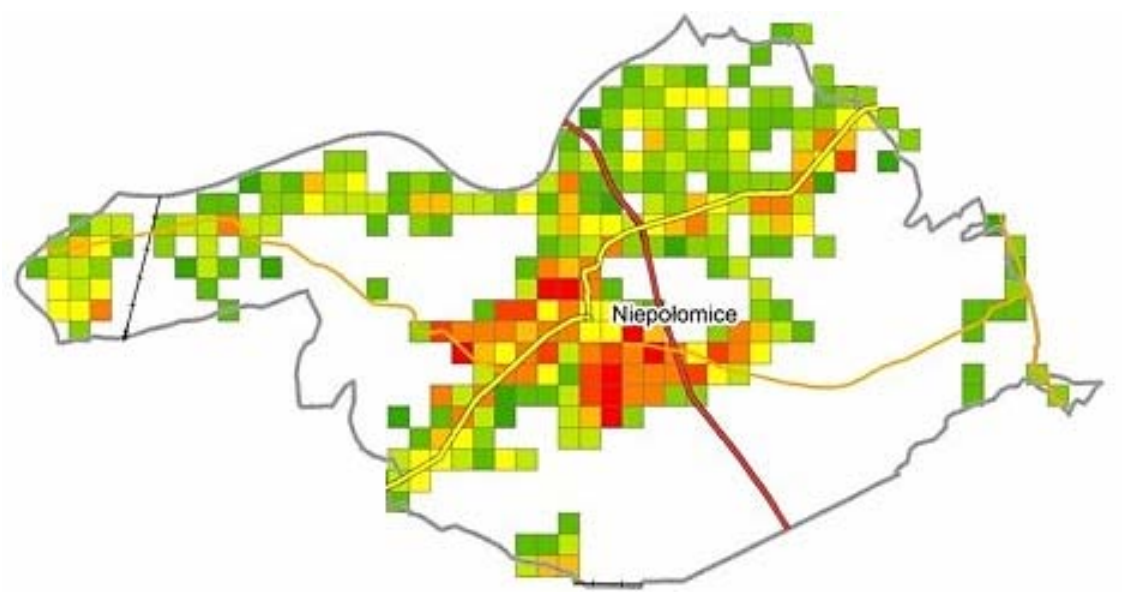

Fig. 6. Population density in 2012 (population per 4 ha); source: E-Niepołomice [undated]

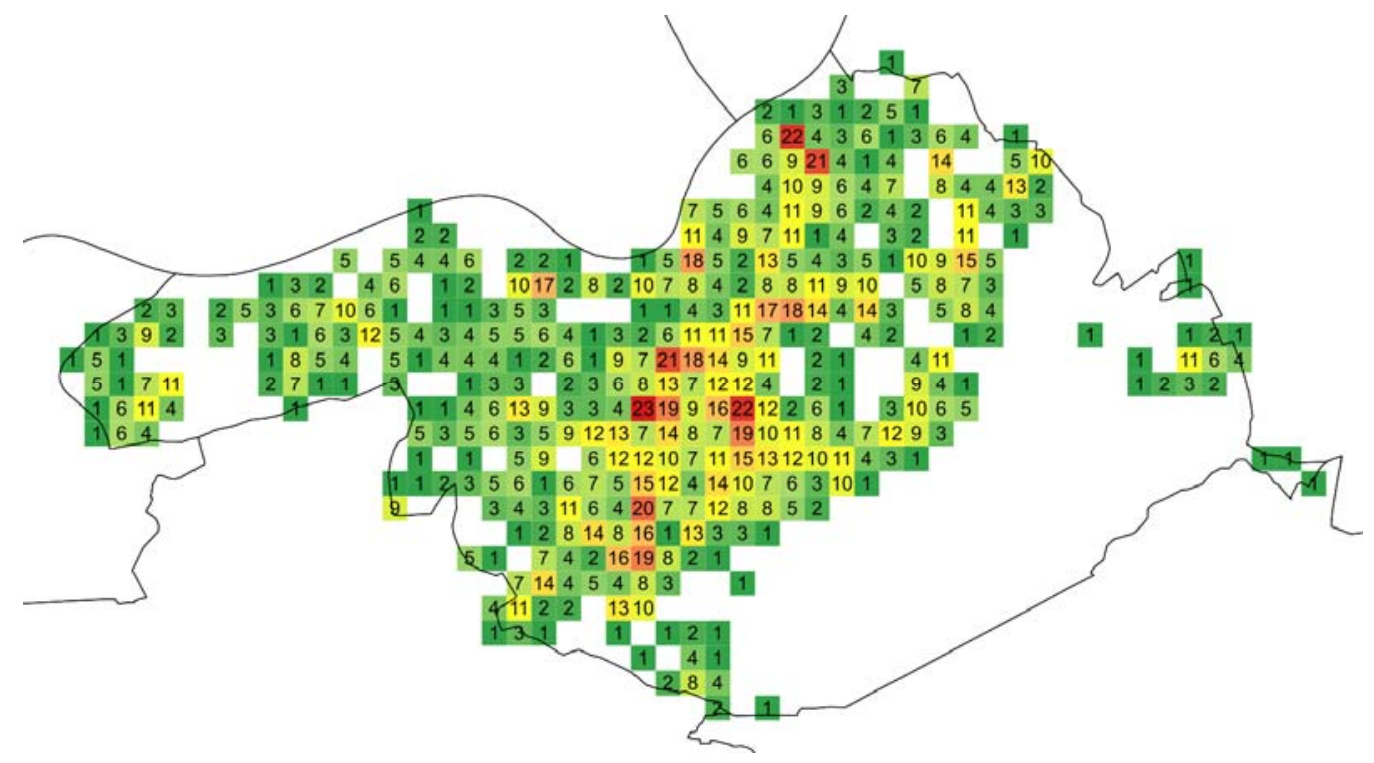

Fig. 7. Density of spatial distribution of record parcels covered by submitted maps for design purposes in the years 2003-2015 (number of submissions per 4 ha); source: own study

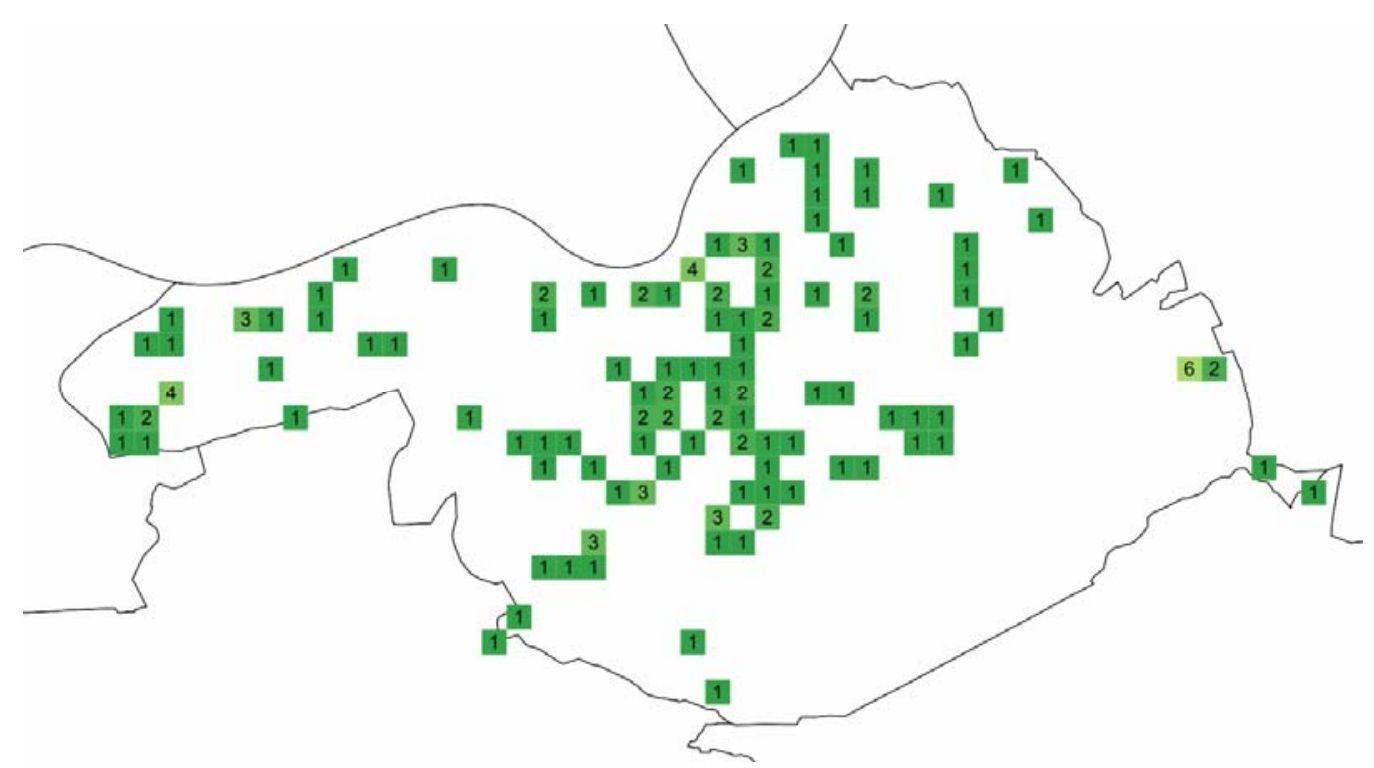

Fig. 8. Density of spatial distribution of record parcels covered by submitted maps for design purposes in the years 2003-2004 (number of submissions per 4 ha); source: own study 


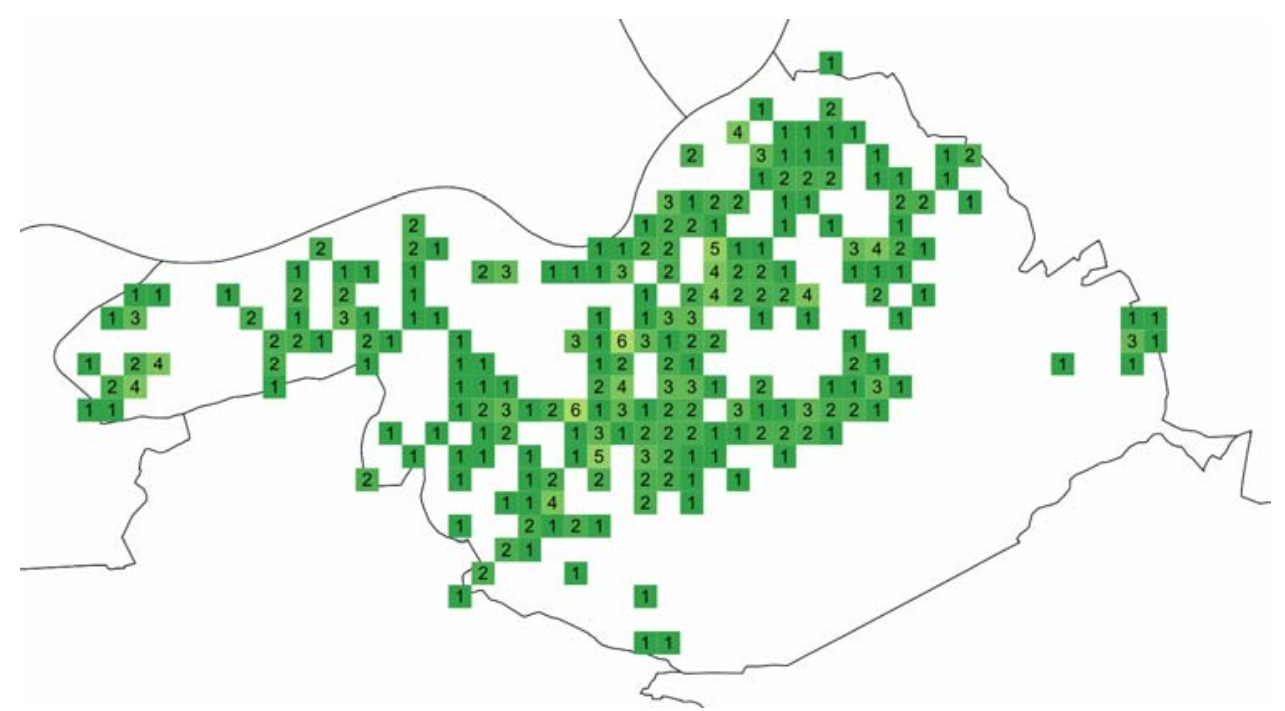

Fig. 9. Density of spatial distribution of record parcels covered by submitted maps for design purposes in the years 2004-2006 (number of submissions per 4 ha); source: own study

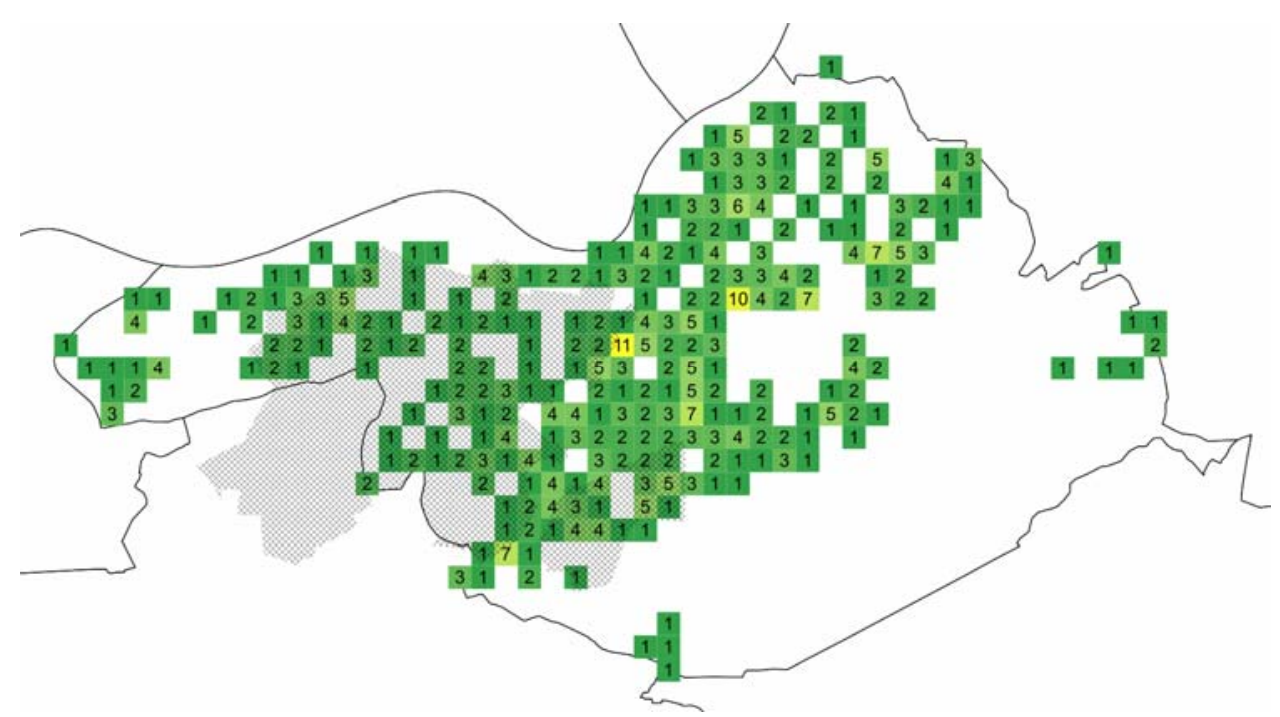

Fig. 10. Density of spatial distribution of record parcels covered by submitted maps for design purposes in the years 2006-2008 (number of submissions per 4 ha) against the 2007 local land use plan; source: own study

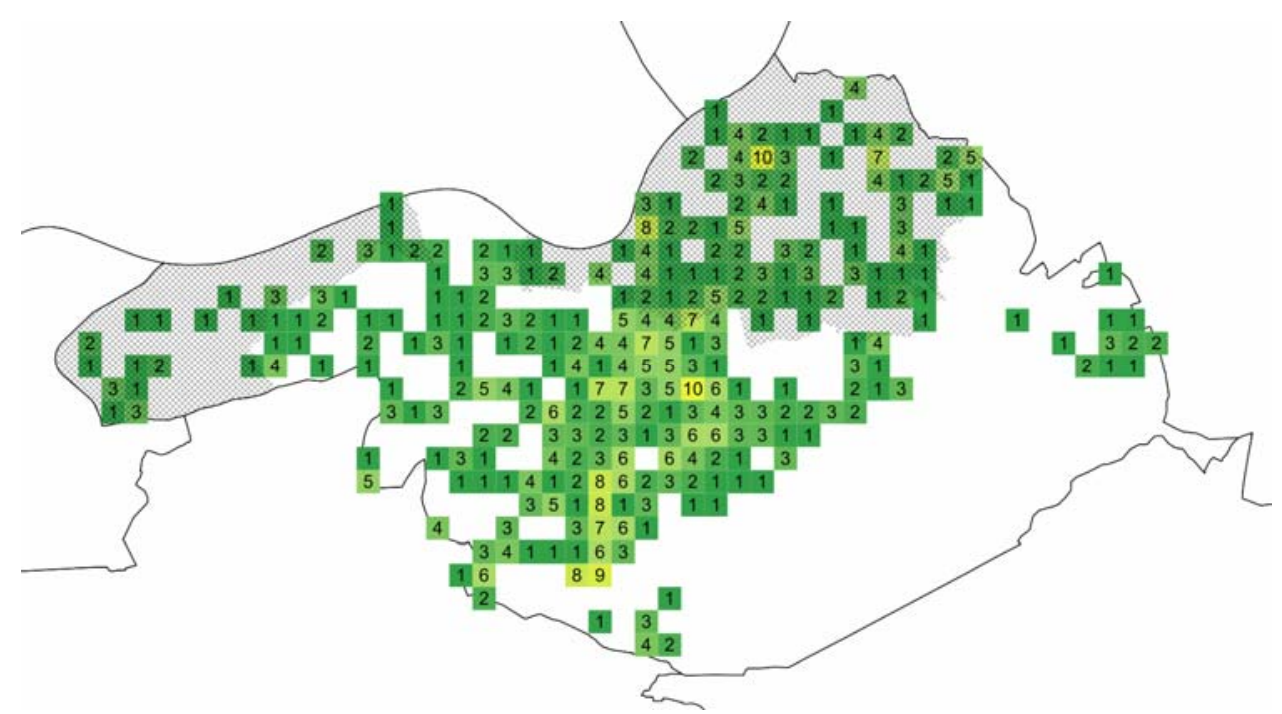

Fig. 11. Density of spatial distribution of record parcels covered by submitted maps for design purposes in the years 2013-2015 (number of submissions per 4 ha) against the 2014 local land use plan; source: own study 
Table 2. Number of submissions of maps for design purposes in 2003-2015 within the boundaries of local land use plans currently in force in Niepołomice

\begin{tabular}{|c|c|c|c|c|c|c|c|c|c|c|c|c|c|}
\hline Plan adopted in & 2003 & 2004 & 2005 & 2006 & 2007 & 2008 & 2009 & 2010 & 2011 & 2012 & 2013 & 2014 & 2015 \\
\hline 2005 & 53 & 32 & 71 & 75 & 88 & 79 & 46 & 87 & 77 & 74 & 18 & 102 & 85 \\
\hline 2007 & 11 & 7 & 18 & 48 & 53 & 61 & 53 & 48 & 55 & 39 & 78 & 61 & 66 \\
\hline 2008 & 0 & 0 & 0 & 0 & 0 & 1 & 0 & 0 & 0 & 0 & 0 & 0 & 1 \\
\hline 2009 & 0 & 0 & 0 & 0 & 0 & 0 & 0 & 0 & 0 & 0 & 1 & 0 & 0 \\
\hline 2010 & 0 & 0 & 0 & 1 & 0 & 0 & 0 & 1 & 0 & 0 & 0 & 1 & 0 \\
\hline 2011 & 4 & 0 & 2 & 5 & 8 & 2 & 9 & 6 & 8 & 2 & 6 & 11 & 10 \\
\hline 2013 & 0 & 3 & 0 & 3 & 3 & 3 & 3 & 2 & 1 & 2 & 3 & 5 & 5 \\
\hline 2014 & 31 & 30 & 60 & 72 & 80 & 80 & 77 & 65 & 75 & 52 & 70 & 68 & 84 \\
\hline 2015 & 0 & 0 & 0 & 0 & 1 & 0 & 0 & 0 & 0 & 0 & 0 & 0 & 0 \\
\hline 2016 & 0 & 0 & 0 & 0 & 0 & 0 & 0 & 0 & 0 & 0 & 1 & 0 & 0 \\
\hline Total & 99 & 72 & 151 & 204 & 233 & 226 & 188 & 209 & 216 & 169 & 177 & 248 & 251 \\
\hline
\end{tabular}

Explanations: years less important for the performed analyses are marked in grey colour. Source: own study.

Table 3. Density of record parcels covered by submitted maps for design purposes in 2003-2015 within the boundaries of local land use plans currently in force in Niepołomice [number of submissions per 1 ha of local land use plan]

\begin{tabular}{|c|c|c|c|c|c|c|c|c|c|c|c|c|c|}
\hline Plan adopted in & 2003 & 2004 & 2005 & 2006 & 2007 & 2008 & 2009 & 2010 & 2011 & 2012 & 2013 & 2014 & 2015 \\
\hline 2005 & 0.06 & 0.04 & 0.08 & 0.08 & 0.10 & 0.09 & 0.05 & 0.10 & 0.08 & 0.08 & 0.02 & 0.11 & 0.09 \\
\hline 2007 & 0.02 & 0.01 & 0.03 & 0.07 & 0.07 & 0.09 & 0.07 & 0.07 & 0.08 & 0.06 & 0.11 & 0.09 & 0.09 \\
\hline 2008 & 0 & 0 & 0 & 0 & 0 & 0.22 & 0 & 0 & 0 & 0 & 0 & 0 & 0.22 \\
\hline 2009 & 0 & 0 & 0 & 0 & 0 & 0 & 0 & 0 & 0 & 0 & 0.74 & 0 & 0 \\
\hline 2010 & 0 & 0 & 0 & 0.77 & 0 & 0 & 0 & 0.77 & 0 & 0 & 0 & 0.77 & 0 \\
\hline 2011 & 0.07 & 0 & 0.04 & 0.09 & 0.14 & 0.04 & 0.16 & 0.11 & 0.14 & 0.04 & 0.11 & 0.19 & 0.18 \\
\hline 2013 & 0 & 0.24 & 0 & 0.24 & 0.24 & 0.24 & 0.24 & 0.16 & 0.08 & 0.16 & 0.24 & 0.40 & 0.40 \\
\hline 2014 & 0.04 & 0.04 & 0.07 & 0.09 & 0.1 & 0.1 & 0.09 & 0.08 & 0.09 & 0.06 & 0.09 & 0.08 & 0.10 \\
\hline 2015 & 0 & 0 & 0 & 0 & 0.36 & 0 & 0 & 0 & 0 & 0 & 0 & 0 & 0 \\
\hline 2016 & 0 & 0 & 0 & 0 & 0 & 0 & 0 & 0 & 0 & 0 & 0.18 & 0 & 0 \\
\hline
\end{tabular}

Explanations: years less important for the performed analyses are marked in grey colour.

Source: own study.

Finally, the annual density of spatial distribution of record parcels covered by the submitted maps for design purposes was determined as part of the preparation of individual local land use plans within the boundaries of the town of Niepołomice. Their number is listed in Table 2 and their density in Table 3.

It appears from Tables 2 and 3 that only local land use plans adopted in 2005, 2007, 2011, 2013 and 2014 had a significant influence on the intensification of investment processes. After they became binding, within their boundaries, there was a slight increase in the number of submitted maps for design purposes per unit area of plan development.

Within the boundaries of the other resolutions, only individual investments were carried out. Very often, maps for design purposes in the areas covered by minor changes were submitted to the District Geodetic and Cartographic Documentation Center in Wieliczka much earlier than the plan. Therefore, it may be concluded that they had nothing to do with the adopted planning documents.

\section{CONCLUSIONS}

Each city or town exhibits a clearly dominant function [PRZEGON 2011]. Niepołomice, however, as a town of outstanding cultural, natural and landscape values, is additionally characterized by its very dy- namic economic and industrial development. As a result of this development, Niepołomice, which have been called a royal town so far, now are slowly transforming into industrial and sleeping facilities for Krakow [WóJTOWICZ-WRóBEL 2008]. Taking into consideration all the conditions, it is very difficult to determine one direction in which the town should develop. Therefore, three functional zones have been identified in Niepołomice, whose activation and organization is based on relevant planning documents.

Over the past several years, local land use plans for Niepołomice create space in accordance with the principle of good neighborhood. Since the Niepołomice Industrial Zone was established, new buildings are erected only by continuation of the existing spatial development.

This raises a concern that the increasing number of detached houses on the outskirts of the town may cause excessive expansion of this type of development and, consequently, may lead to the expansion of the suburban area, where centers appear which are competitive to the historical market [KUPIDURA et al. 2016].

What is important, every time a significant change in the local land use plan took place in Niepołomice, there was also an increase in investors' interest in the area covered by this change. The number of submitted maps for design purposes has increased significantly, not only after the adoption of the local land use plan for 
the town of Niepołomice in 2005 (cf. the diagram in Fig. 3). There are two maxima - 233 in 2007 (introduction of the plan for the Niepołomice Industrial Zone) and ca. 250 in 2014 and 2015 (after updating the plan for the housing estates in the north of the town). It must be remembered, however, that maps for design purposes, which were not always included in the analyses, were prepared to implement an architectural and con- struction project for buildings (residential and nonresidential). They may only be the basis for the extension of such facilities or the completion for linear infrastructure (roads and media).

A relatively small number of submissions of maps for design purposes before 2005 is, of course, due to the lack of a local land use plan. Until then, investments were located based on planning permissions.

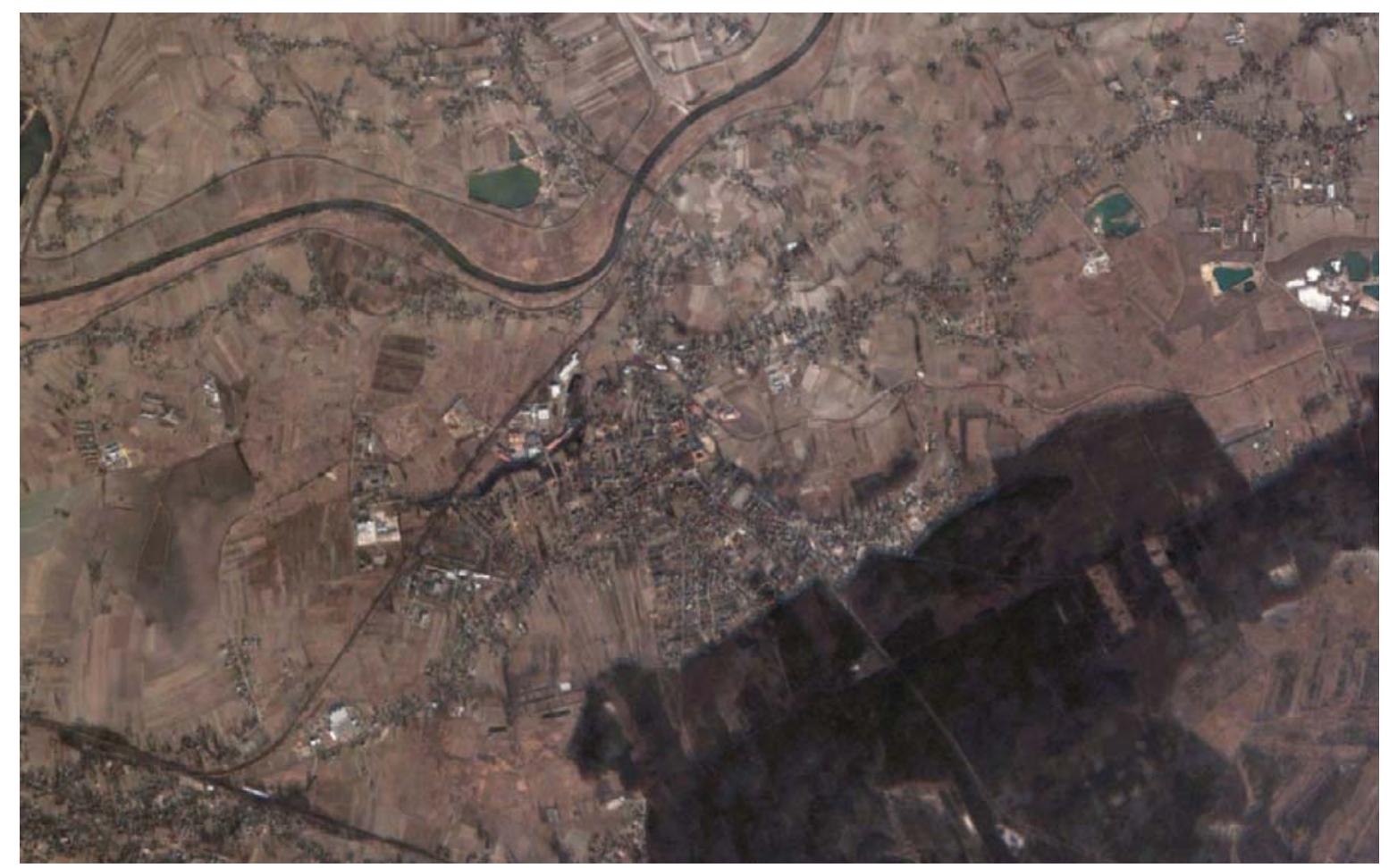

Fig. 12. Orthophotomap of Niepołomice of 24 December 2003; source: Google Earth

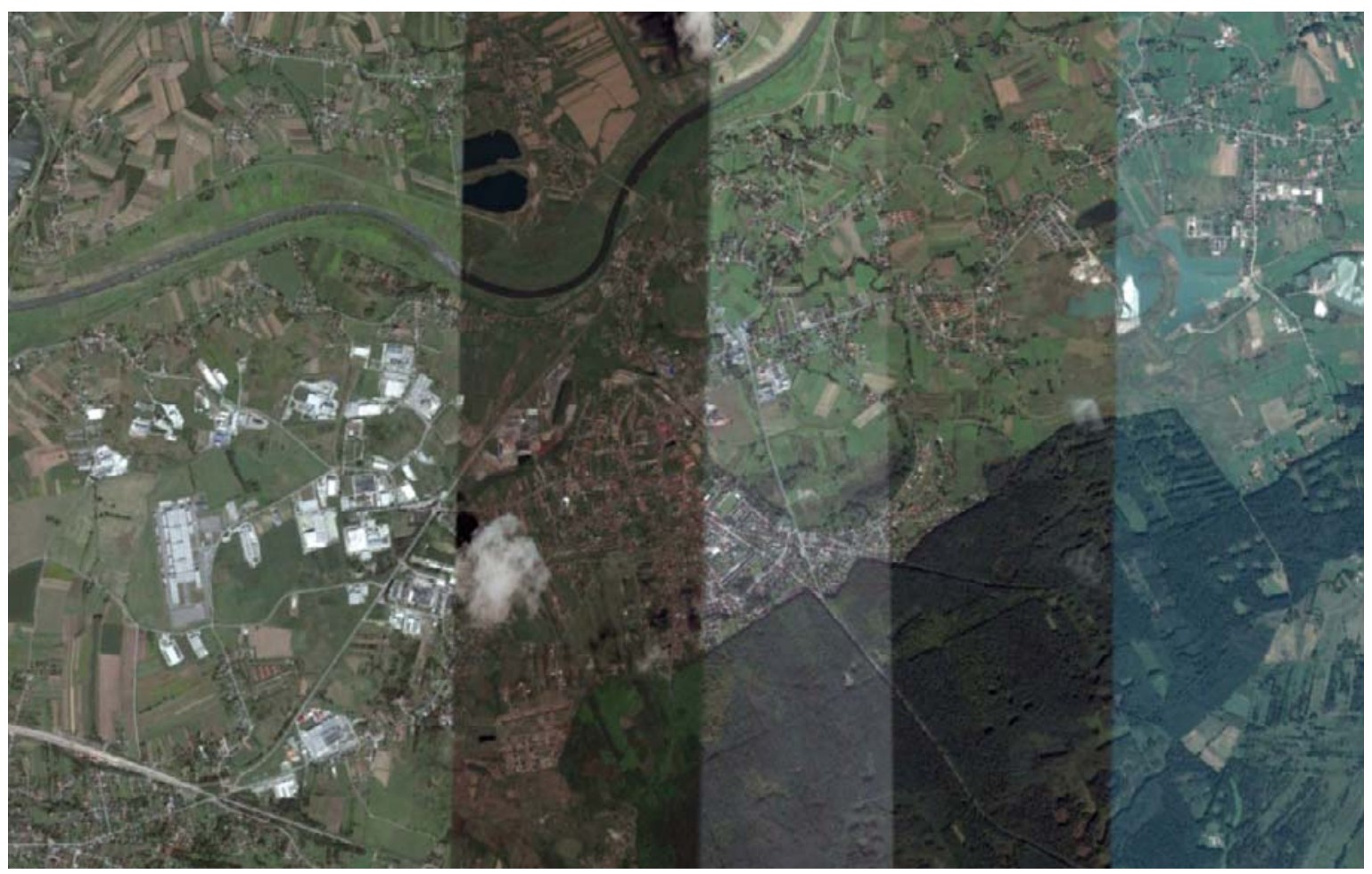

Fig. 13. Orthophotomap of Niepołomice of 24 July 2016; source: Google Earth 
Their issuance was a necessity and thus it extended a preparatory process to commence construction, discouraging potential investors who, knowing about the ongoing local plan preparation process, waited with further decisions for its adoption.

It seems that density of spatial distribution of record parcels covered by maps for design purposes may be an indication of spatial policy conducted in the selected area. In the case of the town of Niepołomice, it has been confirmed that it is possible to use information on the change in the development status illustrated in the documentation accepted into the National Geodetic and Cartographic Documentation Center database in the form of submission of a map for design purposes as an indicator of the correctness of the spatial policy.

To confirm the above analyses, the author decided to present the photos of the town of Niepołomice taken in 2003 (Fig. 12) and in 2016 (Fig. 13).

The above observations imply conducting similar analyses when local land use plans are being updated. They could significantly help to decide whether further expansion of land intended for development should be carried out. Increased number of submissions of maps for design purposes is a good measure of interest demonstrated by potential investors. Their lack, however, proves an unsuccessful attempt to activate a specific area, which should result in giving up activities aimed at modification of a land use plan.

\section{Acknowledgements}

This study has received the financial support from the statutory research No. 11.11.150.006.

\section{REFERENCES}

AdAMczyK T., Begović V., Bieda A., Bielecka E., BUgaj P., DAWIDOWICZ A., DŽUNiĆ I., GAJOS M., JANKOWSKA M., KEREKOVIĆ D., KRUKOWSKA K., KRYSZK H., KUROWSKA K., PARZYCH P., RAHMONOV O., SCHRUNK I., WÓJCIAK E., ŹRÓBEK R. 2014. Spatial data in wide geospace. Zagreb. Nacionalna knjižnica. ISBN 978-953-6129-43-0 pp. 121.

BACIOR S., BIEDA A., KWARTNIK-PRUC A., MIKA M., Pęska A., SiejKa M., TrembeckA A., Wróbel A. 2015. Rola danych geodezyjnych w wybranych procesach gospodarki nieruchomościami [The role of surveying data in selected processes of property management]. Rzeszów. WSIE. ISBN 978-83-60507-22-3 pp. 134.

BALAWEJDER M., NOGA K. 2016. The influence of the highway route on the development of patchwork of plots. Journal of Water and Land Development. No. 30 p. 3-11. DOI 10.1515/jwld-2016-0015.

BIEDA A., HANUS P., HYCNER R. 2012. Geodezyjne aspekty planowania przestrzennego i wybranych opracowań projektowych [Surveying aspects of land use planning and selected design studies]. Katowice. Wydaw. Gall. ISBN 978-83-60968-30-7 pp. 291.

BIEDA A., PARZYCH P. 2013. Development of spatial politics of monumental towns based on Krakow example. International Multidisciplinary Scientific GeoConference SGEM: Surveying Geology \& Mining Ecology Management. Vol. 2 p. 143-150.
BorSA M. 2004. Gospodarka i polityka przestrzenna część II [Economy and spatial policy - part II]. Warszawa. WSSE pp. 96.

CICHOCIŃSKI P. 2007. Zastosowanie metod kartograficznych i geostatystycznych do wstępnej analizy rynku nieruchomości [Application of cartographical and geostatistical methods for preliminary analysis of real estate market]. Studia i Materiały Towarzystwa Naukowego Nieruchomości. Vol. 15. No. 3-4 p. 155-166.

CYMERMAN R., PODCIBORSKI T. 2004. Propozycja metody oceny ładu przestrzennego przy analizie stanu zagospodarowania obszarów wiejskich [Proposal of the spatial order assessment method in the analysis of development satus in rural areas]. Acta Scientiarum Polonorum. Administratio Locorum. Vol. 1. No. 3 p. 31-43.

E-Niepołomice undated. [online] [Access 1.06.2017] Available at: http://www.niepolomice.eu/pl/news_show.php? readmore $=4464$.

Gennaio M.P., Hersperger A.M., BÜrgi M. 2009. Containing urban sprawl - Evaluating effectiveness of urban growth boundaries set by the Swiss Land Use Plan. Land Use Policy. Vol. 26. No. 2 p. 224-232.

GRZYWNA A., SENDER J. 2017. Land cover changes in catchment areas of lakes situated in headwaters of the Tyśmienica River. Journal of Water and Land Development. No. 33 p. 65-71. DOI 10.1515/jwld-2017-0020.

KopaCz M., Twardy S. 2013. Analiza zmian trwałych użytków zielonych w Karpatach na przykładzie zlewni górnego Dunajca i Raby [An analysis of changes in the Carpathian permanent grasslands based on the upper Dunajec and Raba river basins]. Woda-ŚrodowiskoObszary Wiejskie. T. 13. Z. 3(43) p. 91-103.

KORELESKI K. 2009. The system of spatial planning and land management in Poland. Geomatics and Environmental Engineering. Vol. 3. No. 2 p. 27-42.

KUPIDURA A., KARDAŚ A., KUPIDURA P. 2016. Zmiany wybranych elementów krajobrazu strefy pośredniej i zewnętrznej małego miasta na przykładzie Gołdapi i Sulechowa [Landscape changes of small town middle and external zone]. Studia Ekonomiczne. Vol. 279 p. $188-196$.

MACLAREN V.W. 1996. Urban sustainability reporting. Journal of the American Planning Association. Vol. 62. No. 2 p. 184-202.

Miasto i Gmina Niepołomice undated. System Informacji Przestrzennej [Spatial Information System]. [online. [Access 1.06.2017]. Available at: niepolomice.e-mapa. net

PIASECKI A., JURASZ J. 2015. Urbanizacja a stan gospodarki wodno-ściekowej na przykładzie obszaru podmiejskiego Torunia [Urbanization and the status of water management and sewage disposal - a Toruń suburban example]. Woda-Środowisko-Obszary Wiejskie. T. 15. Z. 4 (52) p. 19-28.

PRZEGON W. 2011. Zmiany użytkowania ziemi na przykładzie miasta Podgórza i Zamościa [Changes in land use on the example of Podgórze and Zamość]. Kraków. Wydaw. Nauk. Akapit. ISBN 978-83-926452-8-3 pp. 198.

Salvati L., Munafo M., Morelli V.G., SabBi A. 2012. Low-density settlements and land use changes in a Mediterranean urban region. Landscape and Urban Planning. Vol. 105. No. 1 p. 43-52.

ŚLESZYŃSKI P. 2013. Propozycja kompleksowej koncepcji wskaźników zagospodarowania i ładu przestrzennego. W: Wskaźniki zagospodarowania i ładu przestrzennego 
w gminach [Proposal for a comprehensive concept of land development and land use indicators. In: Land use and spatial order indicators in municipalities]. Ed. P. Śleszyński. Warszawa. KPZK PAN p. 176-231.

Uchwała Nr LXIII/629/10 z dnia 27 kwietnia 2010 roku w sprawie studium uwarunkowań i kierunków zagospodarowania przestrzennego miasta i Gminy Niepołomice. Resolution No. LXIII/629/10 of 27 April 2010 on the study of conditions and directions of spatial development of the town and the Commune Niepołomice.

Ustawa z dnia 7 lipca 1994 r. - Prawo budowlane, tekst jednolity z dnia 9 lutego 2016 r. (Dz.U. 2016 poz. 290, z pózn. zm.) Act of 7 July 1994 - Construction Law, consolidated text of 9 February 2016. Journal of Laws of 2016, item 290, as amended.

Ustawa z dnia 27 marca 2003 r. o planowaniu i zagospodarowaniu przestrzennym, tekst jednolity z dnia 13 maja
2016 r. (Dz.U. 2016 poz. 778, z pózn. zm.) Spatial Planning Land Development Act of 27 March 2003, consolidated text of 13 May 2016. Journal of Laws of 2016 , item 778 , as amended.

WÓJTOWICZ-WRÓBEL A. 2008. Metropolitalne uwarunkowania rozwoju małych miast i zmian w ich tożsamości przykład Słomnik i Niepołomic [Small town growth and identity changes metropolitan conditioning - the case studies of Słomniki and Niepołomice]. Czasopismo Techniczne. Architektura. Z. 5-A p. 161-174.

Zhang Q., Wang J., Peng X., Gong P., Shi P. 2002. Urban built-up land change detection with road density and spectral information from multi-temporal Landsat TM data. International Journal of Remote Sensing. Vol. 23. No. 15 p. 3057-3078.

\section{Agnieszka BIEDA}

\section{Intensyfikacja zgłoszeń map do celów projektowych jako wyznacznik prawidłowej polityki przestrzennej}

\section{STRESZCZENIE}

Zadaniem polityki przestrzennej jest ustalenie celów i środków, poprzez które organy administracji publicznej zamierzają kształtować zagospodarowanie określonego obszaru. Polityka ta ma prowadzić do najbardziej racjonalnego wykorzystania otoczenia człowieka. Jest ona wspierana przez planowanie przestrzenne, które za pomocą miejscowych planów zagospodarowania przestrzennego pomaga sprecyzować koncepcję polityki przestrzennej, a także aktywnie uczestniczy w jej realizacji. Planowanie przestrzenne nie może jednak istnieć samodzielnie. Jest ono wyraźnie powiązane z innymi dziedzinami, bez których realizacja polityki przestrzennej byłaby niemożliwa. Branżami skojarzonymi z planowaniem przestrzennym są na pewno geodezja i budownictwo. Opracowania geodezyjne wskazują lokalizację przyszłych obiektów określonych w procesach planistycznych, natomiast obiekty te są realizowane w procesach inwestycyjnych. Z powyższego związku korelacji nasuwa się wniosek dotyczący możliwości wykorzystania procesów budowlanych oraz poprzedzających je prac geodezyjnych jako wskaźnika prawidłowej realizacji polityki przestrzennej. Aby sprawdzić, czy liczba i rozmieszczenie inwestycji mogą być rzeczywiście powiązane z ogólną koncepcją zawartą w polityce przestrzennej, wykonano analizę czasoprzestrzennego rozmieszczenia prac geodezyjnych rozpoczynających procesy budowlane, tj. mapy do celów projektowych w mieście Niepołomice. Uzyskane opracowania kartograficzne porównano z załącznikami graficznymi do dokumentów planistycznych powstających w odniesieniu do obszaru zawartego w granicach administracyjnych miasta. Badania przeprowadzono dla lat 2003-2015.

Słowa kluczowe: mapa do celów projektowych, mapa gęstości, miejscowy plan zagospodarowania przestrzennego, polityka przestrzenna, proces budowlany 